\title{
Psychological Dimension and Relevance of Nigerian Educational Policies: Parent's Perceptual Approach
}

\section{| Tony Ganagana |}

Department of Educational Foundations, Niger Delta University, Wilberforce Island, Bayelsa State, Nigeria

drtganagana2006@gmail.com

\begin{abstract}
The paper explored the depth of psychological content that can be found in the Nigerian educational policies formulated over the years, and its relationship with their relevance to the needs of the people. To ascertain this parental responses of how they perceived the effectiveness of each of the educational policies they have witnessed from the colonial days to the presence were obtained. Parents who were between 55 years and 80 years were used in the study. Sample size was three thousand, two hundred and sixteen parents. They were to complete a rating scale entitled Educational Policy Psychological Rating Scale (EPPRS). Reliability coefficient of the instrument was 0.76. Being historical in design, data was analyzed with descriptive statistics. Findings revealed that the psychological contents (dimensions) of all the educational policies formulated so far in the country was low (Mean points < 50) and that the Pre-independence Educational Policy had the highest psychological elements (MP > 50). The psychological dimension as provided for in most of the Nigerian educational policies is grossly inadequate for policy effectiveness. It was further discovered that those educational policies that possessed low psychological background (dimension) also had lowered degree of relevance in addressing the needs of the people. Since psychological dimensions closely impinges on policy relevance, it was recommended among others that one of the emphases in developing educational policy is the provision of a rich psychological background in the policy. KEYWORDS

psychological dimension; educational policy; perental perception; pre and post independence educational policy; Nigerian education
\end{abstract}

\section{INTRODUCTION}

Nigeria as a nation has undergone series of experiences since independence in 1960. These national experiences sometimes metamorphosed into gains in nationhood, while at other times, they posed as real challenges. Being an independent nation; Nigeria has her array of needs. Most of these needs are tackled at the government levels through policies and programmes. One of the ways, Nigeria strives to tackle her needs especially in the area of educational development is through education policies. From the colonial days to modern, Nigeria has initiated several education policies based on her national needs. But for the purpose of efficiency and utility, these policies must possess inherent values and standards.

A policy is an agreed term of what is to be done; a set of plans or actions agreed on by a government, political party, business or other group (Rundell, 2007). Educational policy is therefore, a guide showing clear-cut statement of mission portraying all that is intended of government in the area of educational development. Having identified the specific action area educational policy then prescribes the means to achieve those aspects of its national objectives that have to rely on the use of education as a tool (Osokoya, 2010). Nigeria has 
witnessed a lot of educational policies ranging from traditional policies to the colonial through the post-colonial. Each of these educational policies are unique in their own right. However, the general purpose of an educational policy is to provide a guide in the process of transmitting cherished societal values for the utmost development of the society.

Values are of different types. Ferari (2018) identified traditional values as core values to be promoted in the society, whereas Adenuga (2018) related religious values as apt for nation building. Development and promotion of these values may constitute the basic needs of a society. These cherished values, however have philosophical, sociological, psychological and even cultural or historical connotations. If these cherished values are to be attained or achieved through education as a tool highlighted by Osokoya (2010), then the educational policy that has envisaged or incorporated these values must be further processed. This will fully bring to bear the educational system that is capable of attaining the envisaged societal values.

But educational policy must meet the aspirations of the people. Education policies usually produce the school system through which the process will be harnessed, and the values and the aspirations of the people are being promoted. Therefore, the degree to which educational policy conforms to the perception and aspirations of the people define the degree in which the educational policy is accepted and responded to. The school does not function in this direction alone. It functions with the curriculum. The curriculum also originates from the government which initiated the educational policy. One sure way in which acceptance or support of the educational policy is evident in parental responses to the policy or the school system. This is where the psychological dimension comes to play.

So, the fact that education policy gives birth to the curriculum and the school system does not in any way undermine the importance of the psychological dimensions or application. All of the above mentioned structures or agencies through which society intend to inculcate its cultural values and skills, and needs satisfied must be driven by 'psychological accessories.' - the human being, his mind, faculties and personality. Besides, human beings who are at the centre of the operation e.g. the teacher in the school, the learner and the stakeholder (players) or parent are all fundamentally psychological. Thus, Mkpa (2004) and Emeh (2007) observed that the curriculum that can effectively serve the school or the educational system must possess historical, philosophical, sociological and psychological foundations. Educational policies can therefore be defective where any of these prime movers are absent. Emphasis on the psychological dimension will bring in huge benefits to the educational policy and to the operation of the school system. Psychological dimension guarantees psychological relevance in the educational policy. The resultant effect is seen in the response or reactionary patterns of parents and other stakeholders which sometimes, is evident in the lopsided execution of the policy, and hindering wholesomely achievement of objectives. A high level of psychological elements or contents in the educational policy determines the psychological dimension and the relevance of the policy. This is common in most Nigeria's educational policies. Over the years, most people are dissatisfied over the education system especially as regards to quality or standards. It is often observed that difficulties set in either at the point of analysis of the policy or functioning level in the school system or curriculum development and implementation stages. These difficulties may to a large extent be due to neglect of the psychological dimension. A careful organization of education policy and the development of the curriculum with an adequate psychological background would proffer effective solutions to difficulties in the planning, development and implementation of the educational policy. At one time, difficulties set in the identification of the psychological dimension, and at another out of inadequate expression 
of contents. These can be tackled with the involvement of people with vast psychological knowledge.

\section{Statement of the Problem}

There has been a growing concern in the country over the quality of our educational system. People openly claimed that the standard of education in Nigeria has fallen. This assertion is coming mostly from parents and high level stakeholders. However, this fallen standard as acknowledged may not be directly linked to government initiatives but rather some external factors which may be largely psychological.

Over the years, the Nigerian government has developed policies aimed at sustaining an improved educational system. This is done through the educational policies that government has initiated from time to time. So far educational policies that have come into existence within the period can be categorized into the Colonial Educational Policy, the Preindependence and Post-independence Educational Policies, and the New National Policy on Education. All of these are efforts of government towards providing quality education to her citizenry. But it seems that the more efforts government is making in this respect, the more the educational system is adjudged to have been faulty or at best, not making the desired impact. This has created an illusion in the mind of the people whereby Nigerians prefer sending their children/wards to acquire education abroad, thereby draining the nation's foreign reserves. Besides, this perception of the people has made nonsense of government's efforts towards education which perhaps led to the situation where government now pays non-challant attitude towards educational issues in the country.

Furthermore, employers of labour are complaining that the nation's schools are no longer producing quality workforce to man their industries. This scenario is due to government not imputing or considering enough psychological elements in educational policy initiatives. A significant amount of psychological contents (dimensions) or elements in the educational policy will highly promote relevance of the educational policy. This is because it is the psychological dimension that can sufficiently address issues of the mindset of the people, their perception, thoughts, attitude and reaction or behaviour towards the educational policy.

It therefore goes without saying that, the fallen standard of education and in fact, the whole of the issues raised in the educational system is due to lack of giving enough emphasis of the psychological dimension into the planning and execution of educational policies in Nigeria, which in turn affects the nation's educational system.

The paper therefore attempts to examine the extent psychological dimensions (factors) were provided for in all the educational policies so far initiated by government. Where psychological elements are entrenched in the educational policies or educational system, it would ultimately be evident in the perception and reactions or behaviour of the parents and the people (stakeholders) towards the policy or educational system. This paper is therefore focused on assessing how parental perception of each of the educational policies of government has affected their attitude or response towards the educational or school system at the dawn of each educational policy.

\section{Theoretical Framework}

Maslow's theory of needs is apt in this study. Maslow (1954) highlighted that the individual's needs motivate or arouse him towards goal achievement. He identified five categories of human needs which are arranged in forms of hierarchy. At the base of the hierarchy, Maslow identified physiological needs which involve all the conditions that border on provision of food, shelter, warmth and sex. A little further apart are the safety needs which involve security, protection, self-preservation and family stability needs. Next 
in the hierarchy is love and belonging needs which include the need for affection, personal acceptance, friendship and group affiliation needs. This is followed by esteem needs in the hierarchy. It is concerned with the need for self-confidence, self-respect, competence, recognition and integrity. Then at the apex of the hierarchy is found self-actualization needs. These involve the needs for self-fulfilment, ambition and achievement of goals.

Maslow's $(1943,1954)$ opined that these needs are arranged in such a way that when the lower needs have been met, then the next higher need will emerge. For instance, where the physiological needs are successfully met, then safety needs eventually occurs in the individual.

It is necessary that the educational needs of the family or that of the society precipitate the education policy. Maslow's theory therefore attempts to explain the needs of the society as well as those of the individuals in the society. Here, educational needs of the individual or the society are presumably explained in the five hierarchies of needs. Hultsjo (2010) stated that family needs range from food, shelter, warmth, (basic needs) to those of cultural. Individual needs could follow the same pattern. For instance, the need for competence and recognition in the society make many people to go to school. Again, most of the purposes of schooling fall under the needs for competence and recognition as well as to gain respect. Sharma's (2019) capitulation can also be seen in that light. In other words, someone who goes to school would want to stand out of the crowd, that he or she would want to be specially respected and recognized for his worth and/or competence. If the people perceive that the educational policy could guarantee them this desire of theirs then the psychological aspect is beginning to be covered. For the purpose of schooling for most people is to attain selfesteem and secure ones future or the future of the family. The issue of esteem needs is key especially in the area of recognition, competence and preservation which can be needs to the individual or the family. The other is the issue of respect. From Sharma's (2019) highlight, someone who conserves or promotes his culture wants to be respected and recognized as an individual of worth. In the same vein, someone who thrives for development or for social responsibility would as well be accorded with respect and recognition. More so, someone who is aligning to citizenship or civic responsibility and adjusting to the realities of the society is looking for respect, acceptance and recognition. Acquisition of vocational skills and commitment is striving toward competence, respect, recognition. preservation and for family stability. Thus, the psychological dimension focuses on how parents or people perceive the extent the educational policy could either in writing or practice help them achieve their individual goals and react accordingly.

\section{Educational Policy and the School}

Every educational policy, ultimately heralds the school system. Inevitably, the school defines the educational system derived from the educational policy. The school is a space where learning takes place. Education policy implicitly provides for learning experiences. It is the school that harnesses all the necessary paraphernalia to explicitly define the learning experiences through the curriculum for effective inculcation and utilization. These learning experiences which takes place in the school system, according to Tyack (1988), are designed to incorporate social and economic needs. In other words, they are designed to promote social and economic values in the society. These values are actually the needs of the society. But to tackle these needs and achieve success, society has to use a fundamental human driver or asset, which is the mind. The human mind is therefore very essential in choosing learning experiences, and in learning and application of what has been learned, be it culture, social behaviour or philosophical, all made possible with the 'psychological software' of the mind. 
Demarrais and Lecompte (1995) suggested three areas or purposes for which the learning experiences must cover. These are intellectual, political, economic and social purposes. Psychological values are also implied here, in that schooling among other factors promote social and other purposes. Philosophically, Adler (1982) maintained that the objectives of the school are the development of citizenship, personal growth or self-improvement and occupational preparation. Adler's (1982) proposition mainly highlighted the psychological implications or dimensions of schooling. For psychology deals with developmental and growth issues as well as self-competence and vocational concerns.

In line with the above, Sharma (2019) highlighted seven functions of a school to include:

(i). Conservation and promotion of culture

(ii). All-round development of the individual

(iii). Development of higher values of life,

(iv). Development of social responsibility

(v). Citizenship training

(vi). Adjustability in society

(vii). Vocational training

If these also define the goals of education, then it has to be carefully examined in the light of psychological foundations. A careful understanding of the purposes and functions of the school as highlighted above reveals that the foundational bases of providing for philosophical, sociological, historical and psychological relevance are encapsulated by all the authors reviewed. For instance, the whole of Sharma's (2019) assertion can be thus examined and presented in a table as seen below.

Table 1. Functions of The School

\begin{tabular}{cll}
\hline S/No & Objectives of school & Foundations derived \\
\hline 1 & Conservation and promotion of culture & Historical \\
2 & All-round development of the individual & Philosophical \\
3 & Development of higher values of life & Sociological/psychological \\
4 & Development of social responsibility & Sociological \\
5 & Citizenship training & Sociological/Philosophical/Psychologica \\
6 & Adjustability in society & Psychological \\
7 & Vocational training & Psychological/sociological/economical \\
\hline
\end{tabular}

The school objectives have the above foundational framework because this is the spectrum of societal needs. Societal needs or goals are derived from or being fulfilled by individual needs. Sometimes the same are the needs of the family. Thus, the individual, family and society may harmonize in their needs or goal orientation. Where this happens objectives are easily fulfilled. For instance, for the psychological dimension, much of it is embedded in self-esteem, self-fulfilment and self-development. Weber (2010) and Baumgardener (2019) observed that families sometimes have esteem need, also. So the way and degree with which individual members of the family seeks for self-esteem may also climaxed into family's esteem need. Much of it in the family is therefore determined by the parents or adult members of the family. Self-esteem need is the need to persistently promote and preserve ones self-concept. It is the need to hold oneself in high regard in respect of circumstances.

So educational policy that does not subscribe to this foundational framework or psychological background in its development and even implementation stages will be ineffective in its operation. This is so because the educational system and the school with its inherent nature, will find it difficult to implement and actualized the objectives of the educational policy, where goals or needs do not harmonize. 


\section{Educational Policy and the Currculum}

As already pointed out, the curriculum is the product of the educational policy and a complement of the school system. The curriculum contains the teaching and learning experiences which the school would harness for the achievement of the objectives of the educational policy.

The curriculum is concerned with the courses of study in the school or academic programme and how this can be implemented. However, in an attempt to describe what the curriculum is, Whitson (2017) offered several alternative definitions which include:

(i). The curriculum is what we teach, both written and unwritten in the school.

(ii). The curriculum is the programme of instruction, which should be based on both standards and best practice research as well as the framework teachers use to plan instruction for their students.

(iii). Curriculum is not only all the courses of study offered at a University or school but were specific and work objectives, performance indicators, philosophies and ways to approach these objectives.

(iv). A selection of information, re-gregated into disciplines and courses, typically designed to achieve a specific educational objective.

(v). A curriculum is the combination of instructional practices, learning experiences and students performance assessment that are designed to bring out and evaluate the target learning outcome of a particular course.

(vi). Curriculum refers to an interactive system of instruction and learning with specific goals, contents, strategies, measurement and resources with the desired outcome being successful transfer and for development of knowledge, skills and attitudes.

(vii). The curriculum contains intended objectives, learning activities, content organization and evaluation (Benwari, 2014). According to Lein-Ratman (2018), the curriculum is meant for teachers to actualize it in the students. This suggests that teachers should carryout School Based Curriculum Development (SBCD). The curriculum is therefore the major reliance of the school as regards to learning. Thus; in terms of the curriculum, emphasis is placed on the teacher and the students; but no attention on the parents and other stakeholders. But at the policy level, this should not be so.

The curriculum, no matter how, it was developed should have a foundational framework. As mentioned earlier, Mkpa (2014) and Emeh (2017) had asserted that the curriculum should necessarily have historical, philosophical, sociological and psychological foundations. In line with this, Kan (2019) opined that the curriculum elements must reflect the society and culture, and that these are the foundational basis of the curriculum. He thus identified five common basis of the curriculum. These are the philosophical, psychological, socio-cultural, historical, and economical bases. (Kan, 2019). Each of these foundational bases has its specific elements. For instance, Kan (2019) asserted that the psychological foundation of the curriculum focuses on the learning experiences and the learner. He further stated that the psychological foundation is also concerned with individual differences and that every student has its own unique personality and also that they have differences in learning and skills development. These psychological aspects first centred on the learner, the other aspects of the psychological dimension should focus on the perception of the education policy by stakeholders, parents and consumers of the educational products, attitude as well as aspirations of the people. These group can adequately evaluate the utility of the educational policy and how effective it has been in terms of standards and relevance to skills development and to the diverse employment needs in the society. Besides, the psychological 
dimension of the education policy is also concerned with its relationship to self-esteem needs and competencies which leads to rapid societal advancement.

\section{Psychological Dimensions of Educational Policy, Parental Perception and Response}

Educational policies are objectives peculiar to the society that would be achieved through the tool of education. Educational policies are therefore very important documents of the government. To achieve its effectiveness, the psychological relevance must be highly emphasized. The psychological considerations or foundations must go beyond the basics of stressing the importance of the learner or the position of the government in the formulation of the policy to the emotional aspects of the learners. The society is made up of individuals. Therefore, beyond the learner, the position of every individual in the society has to be carefully considered all together. This looks like a mild issue but impact largely on the gains of education policies. Thus, while the basic or elementary consideration of the psychological foundations is directed towards reforms and the capability of the child to learn, it should go further to consider the future outcome of the individual after training, the behavior of the educated individuals in the society and to what extent they feel competent and committed to the society as a group, as well as their reactions and adjustment or behavioural patterns based on the perception of their environment. On the whole, the psychological dimension of any education policy must focus on the learner, his characteristics, aspirations, motivational level, strategies or methods of facilitating learner's capabilities, peculiarities, interests and initiatives of the learner.

Furthermore, emphasis should be placed in the education policy the psychological issues surrounding group dynamics, perceptual levels of groups or individuals, interrelationships among groups and how individuals constituting the society perceives, feels and responds to educational issues as a group. This is the necessary consideration and complement of the psychological issues that must be considered in every educational policy and/or the educational system. It was Adler (1982), who opined that behavioural patterns either as individuals or group are strivings against inferiority complex and for superiority and perfection. For Maslow (1954), such behavioural patterns (motivators) of individuals or groups are for the attainment of self-esteem or self-actualization. These are psychological indicators and the reason why, the individual learner, family dynamics and the members of the society should be considered as a whole in harmonizing societal or national needs.

Psychology deals with the individual and the way, he behaves and his probable behavior paradigms based on prevailing stimuli. Psychology is the core and foundation element of all the learning processes. This affects the child's mental development, teaching methods, learning theories, Administration of educational system and planning, character building of the students, attitude of students, and teachers, the society and the use of different technologies.(Kan, 2019). Parents as members of the society are related to all of these variables.

Furthermore, parents play dominant roles in the education of the children, so their perception of the educational policy or the educational system can define the effectiveness or usefulness of the policy. The task of the parents is to ensure that educational opportunities available offer optimum benefits to their children/wards. Where the psychological bearings of the parents are in line with the education policy, that part of the policy will attract massive patronage of learners. This is because parents direct their children/wards that constitute the learners in these areas as they deem relevant to them in the policy. As earlier pointed out, this role is based on individual and family needs. Identifying major educational policies in Nigeria and how parents perceive and respond to them is a major way of establishing the psychological dimension and usefulness of education policies. 


\section{The Colonial Educational Policy in Nigeria}

The colonial educational policy in Nigeria can be seen in two perspectives viz, missionary activities and their establishment of schools with their own educational policy and the government stepping into education with their own educational policy as well. The missionaries were very committed with the establishment of schools, and running them with some religious flair. Their emphasis in education was literacy and the ability to the read the Bible. But in 1877 the colonial administration in Nigeria first indicated interest in education and provided the missionary schools with some funds especially in Lagos. Later an education ordinance was promulgated in 1882 known as the 1882 education ordinance (Osokoya, 2010).

With the 1882 education ordinance, the Nigerian government took over schools from the missionaries. According to Osokoya (2010), the 1882 education ordinance was shifted by the introduction of another education ordinance in 1887 which led to the establishment of primary schools as well as industrial schools as against the standard schools.. But this was to lead to the birth of another ordinance known as the 1925 education memorandum. The aims and objectives of the 1925 educational memorandum was far beyond literacy as was the order of the day. Thus, the 1925 educational memorandum provided for the establishment of the following.

(a) Elementary education for boys and girls beginning with the education of young children.

(b) Secondary or intermediary education

(c) Technical and vocational schools

(d) Higher education to reach University rank

(e) Adult education

It was this early colonial intervention in education that led to the establishment of University College, Ibadan after setting up series of educational commissions for more reforms (Osokoya, 2010), According to Fafunwa (2004) the appointment of Mr. Eric Hussey as the first director of education of Nigeria in 1929 and the establishment of University College, Ibadan in 1948 was a major landmark which broadened the objectives of the colonial education policy. Education was now pushed beyond the emphasis of literacy. It was now made to take-in some level of intellectual lineage and high level skill development and training. As dynamic as these reforms were the question remains to what extent does the psychological dimension covered by the colonial educational policy. According to Amba (2012), the colonial educational policy commanded effective patronage as the products were skillful and highly literate. So the standard school graduates were rated high. This policy perhaps, would have possessed a good amount of psychological contents.

\section{The Pre-Independence Education Policy}

Before Nigeria attained independence, there were some regulations about education in the area. This centred around the education ordinances immediately before the country attained independence. Series of events took place within this period leading to the birth of several education commissions or ordinances. This period witnessed the introduction of free Universal Primary Education (UPE) which begin in the Western Region of Nigeria in 1952. Implementation of the UPE in most parts of the country was met with some difficulties. However, education was funded by both the government and voluntary agencies as well as the missionaries. In September, 1960, the Ashyby commission was established, and this development saw to the expansion of the primary, secondary and higher institutions. The aim of education was therefore stressed beyond literacy to technical and vocational gains. 
Moreso, university education was expanded with the establishment of the subordinate institutions in the same perspectives of the government.

The Pre-independence education policy actually led to the establishment of more universities in the country in 1962 . The country now had five universities. They include Ahmadu Bello University, Zaria, University of Nigeria, Nsukka, University of Ife and University of Lagos. The initial University College, Ibadan now became University of Ibadan.

With this development above, education was now moved beyond mere literacy to include manual, technical or vocational training. Consequently, agricultural schools such as the ones in Akure, Moor Plantation Ibadan, Samaru and Umudike were expanded. Technological institutions and Polytechnics also sprang up in 1965. Were these reforms also made to care for the psychological dimension. As earlier pointed out the psychological dimension of the policy actually deals with psychological constructs arising from the policy.

According to Wrings (2009) the Pre-independence Educational Policy actually impacted on the gains of people. It appeared to have met the aspirations of all in the country. People expected that this particular educational policy should be sustained. This is because graduates from this system were sound, skillful, and commanded recognition, self respect and self-esteem. A lot of privileges were accorded these graduates and employment opportunities were high, and this boosted their self-concept. So people wholesomely accepted and supported the policy. But soon, government saw the need for improvement.

\section{The Post-Independence Education Policy}

Further improvement of the national policy of education was drawn from some committee reports throughout the country. Primary education was further advanced with the launching of the Universal Free Primary Education Scheme in 1976. Under this Scheme primary school was to last for six years. Teaching and learning under the primary school should be properly monitored. Teachers were to be trained in their various categories and teachers' welfare should be taken seriously. The hitherto poor treatment of teachers was now a thing of the past where teachers were to occupy similar offices and privileges accorded to Ministry workers. This raised their lowered self-image and increased their productivity.

With the introduction of 1979 constitution, primary education was no longer funded by the federal government of Nigeria. It was now the responsibility of the states and local government councils. Other decisions taken was the establishment of the National Teachers Institute which wield control over the quality of teacher education in Nigeria. Again, the Post-independence Education Policy led to the creation of the secondary grammar schools and the secondary modern schools as well as secondary technical schools. Then again, the comprehensive secondary schools which curriculum was detailed now emerged. Furthermore, teacher training colleges and the National Certificate of Education (NCE) were introduced. This was followed by the establishment of "second generation" universities in the country. They were universities of Jos, Benin, Calabar, Illorin, Sokoto, Maiduguri, Port Harcourt and Bayero, Kano. It was also during this period that 'third generation' Universities also sprang up with the establishment of seven universities of Technology e.g Bauchi, Makurdi, Owerri, Akure, Yola, Abeokuta and Minna between 1981-1983. The PostIndependence Education Policy also gave birth to many State universities. This landmark improvement in education was to meet with the middle and high level manpower needs of the nation.

According to Okechukwu (2007), as detailed and comprehensive as this policy was, it seemed that no further Policy would have been necessary in the immediate future. This renders a plausible fact that the standard of education would have been high. Yet, 
comprehensive arrangement may not be a necessary complement of effectiveness. So, the Post-independence Educational Policy did not successfully meet the needs and aspirations of the people. There is need to understand and consider more of the psychological dimension to effectively complement this policy. Although, parents under this policy, sent their children/wards to Polytechnics and technical schools, their greatest goal was to advance the children to obtain university degree. This led to the polytechnics and colleges of education grossly abandoned as parents insisted on university education for their children and ward. This also explained why the people preferred the secondary grammar schools to secondary modern because of the focus on university education.

\section{The New National Policy on Education}

To further address the issue of achievement of objectives, and effectiveness in implementation, a conference was initiated. This was the 1969 National Conference on Curriculum Development which was held between 8th and 12th September, 1969 in Lagos. It was organized by the Federal Government of Nigeria under the auspices of the Nigeria Education Research Council (NERC). The conference was to deal with the objectives of education, and methods, materials, equipment and aids required for implementing the curriculum in order to achieve the desired objectives. (Osokoya, 2010). Besides, it was specifically designed to provide guidelines on what education system should be accomplishing with respect to:

(i). The needs of youths and adult individuals in the society

(ii). The socio-economic needs, values, aspirations and development of our society.

(iii). The curriculum substance, the subject content of the system which is the means to the goals.

The conference was attended by Vice Chancellors, Professors, Principals of Institutions, Representative of Bursaries, commerce and industry, farmers, civil servants, Professionals, Technicians and Traders and Parents. It was observed by the United Nations Educational, Scientific and Cultural Organization (UNESCO), the Canadian International Development Overseas (CIDO), the Ford Foundations, the British Council and the United State Agency for International Development (USAID). Also, the conference was to evolve a national philosophy of education for Nigerians.

The result of this conference gave birth to the 6-3-3-4 system of education. This means six year of primary education, the secondary schools split into two with three years of Junior Secondary School and three years of Senior Secondary School, and finally four years of University education.

The new policy provided framework for the establishment of pre-primary, primary, secondary, university, technical, special and teacher education, respectively. Besides, educational services, and Administration and Planning as well as financing of education were also highlighted in new national policy on education.

Most striking feature of the policy is the philosophy of Nigerian education which is aimed at achieving:

(a) A free and democratic society

(b) A just and egalitarian society

(c) A united strong and self-reliant nation

(d) A great and dynamic economy, and

(e) A land of bright and full opportunities for all citizens.

But beyond this philosophy was embedded the psychological context where it stated that: The quality of instruction at the educational levels should be geared towards the inculcation of the following values: 
(i). Respect for the growth and dignity of the individuals

(ii). Faith in man's ability to make rational decisions.

(iii). Moral and spiritual values in inter-personal and human relations;

(iv). Shared responsibility for the common good for society.

(v). Respect for the dignity of labour, and

(vi). Promotion of the emotional, physical and psychological health of the children.

Thus, the new national policy on education gave birth to a further expanded educational system. Under the new policy, the Nigerian child would have to pass through six years of primary education, three years of Junior Secondary School and three years of Senior Secondary Schools, and finally, four years of University education. The aim and objective of the secondary school is to equip the students with useful living in the society and to prepare students for a higher education.

The Junior Secondary School is both pre-vocational and academic and free. The schools were to admit every child in school and school drop-out will be taken care of through correspondence courses, radio and television lessons.

The university system should be more professional, scientific and liberalized and would last for four years. Besides, the technical education is proposed to provide for professional, technological knowledge and vocational skills for agricultural, industrial, commerce and economic development. Thus, in the new national policy on education, more leverage was given to foster technical education in the country, which is seen as a basis for the technological advancement of the country. Teacher education was advanced and NCE was made the minimum requirement for teaching. The new national policy in education is in operational since 1982 with a number of modifications at each period (Osokoya, 2010).

No doubt, at face value, the New National Policy on Education seems to possess the necessary foundational and psychological frameworks. With the provisions carefully and purposefully spelt out, it appears to have adequately taken care of the psychological dimension. This can be appropriately determined by the parents and beneficiaries of the education policies which the paper is aimed to achieve through the study of parental perception of the new policy.

\section{RESEARCH METHODS}

The research design for this study is the historical research design. The area of study was Southern Nigeria. South Nigeria is made up of the Western zone (Western Nigeria), Eastern zone (Eastern Nigeria), and South-South zone (the Niger Delta). The study focused on the aged, and the population of the aged people was seventy-three million, seven hundred and ninety-eight thousand, six hundred and thirty-seven. (73, 798, 637); from a national population of over two hundred million people (National Population Commission, 2006), comprising of male and female of not less than fifty-five years of age, and not more than eigthty years. Stratified random sampling technique was adopted to guarantee the participation of respondents in all the three geopolitical zones, thereby giving rise to a total sample size of three thousand, two hundred and sixteen parents that were purposively selected from the three zones that constitute Southern Nigeria.. The breakdown was SouthEast, South-West and South-South zones, respectively. These were thirty-eight, thirty-five and twenty-seven percent of the total sample, respectively. Instrument used was the Educational Policy Psychological Rating Scale (EPPRS), developed by the researcher. It yielded a reliability coefficient of 0.78 , and was considered reliable enough to be used in the study. Parent used were those from 55 years to $80 \mathrm{yrs}$. Administration of instrument lasted for three months with the help of Research Assistants. The instrument had two sections, viz; sections $1 \& 2$, respectively. Section A contained demographic background of respondents, 
while section 2 contained 20 items assessing the psychological dimension and relevance of Education Policies. It was a four-point scale of 'Very high', 'High,'Low' and 'Very Low, which was scored 4, 3, 2, 1, respectively. Descriptive statistics that is, mean and standard deviations were used in analysing data obtained from the instrument.

Table 2. Distribution of Sample Size

\begin{tabular}{clllll}
\hline S/No. & Age & Male & Female & Total & \% \\
\hline 1. & South-east & 634 & 483 & 1117 & 35 \\
2. & South-west & 758 & 478 & 1236 & 38 \\
3. & South-south & 552 & 311 & 863 & 27 \\
\hline & Total & $\mathbf{1 9 4 4}$ & $\mathbf{1 2 7 2}$ & $\mathbf{3 2 1 6}$ & $\mathbf{1 0 0}$ \\
\hline
\end{tabular}

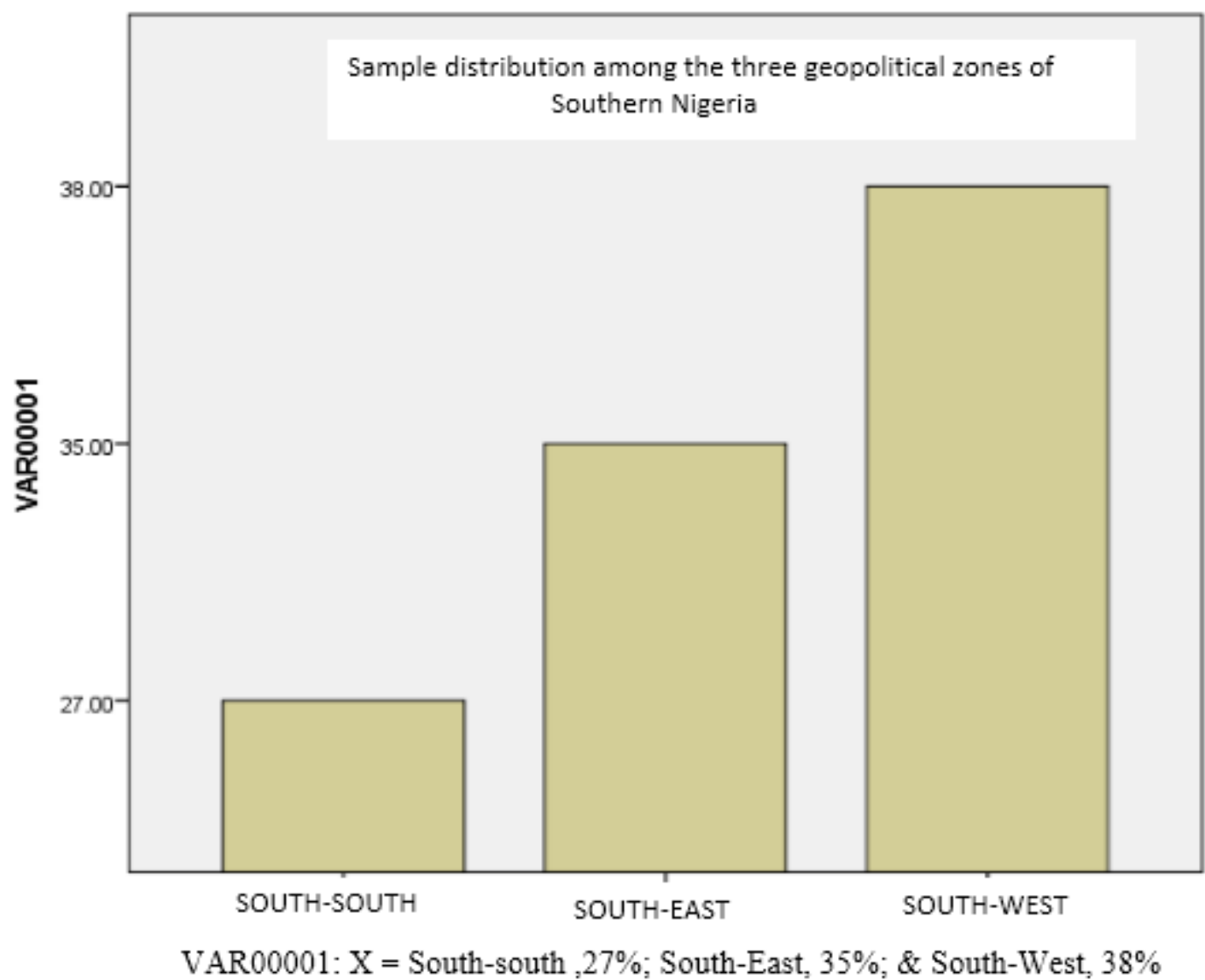

Figure 1. Sample Distribution

Table 3. Description of Respondents by Age

\begin{tabular}{clllll}
\hline S/No. & Age & Total & Male & Female & \% \\
\hline 1. & $55-60$ yrs & 1782 & 1133 & 649 & 55 \\
2. & $61-70$ yrs & 834 & 492 & 342 & 26 \\
3. & $71-80$ yrs & 600 & 367 & 233 & 19 \\
\hline & Total & $\mathbf{3 2 1 6}$ & $\mathbf{1 9 9 2}$ & $\mathbf{1 2 2 4}$ & $\mathbf{1 0 0}$ \\
\hline
\end{tabular}




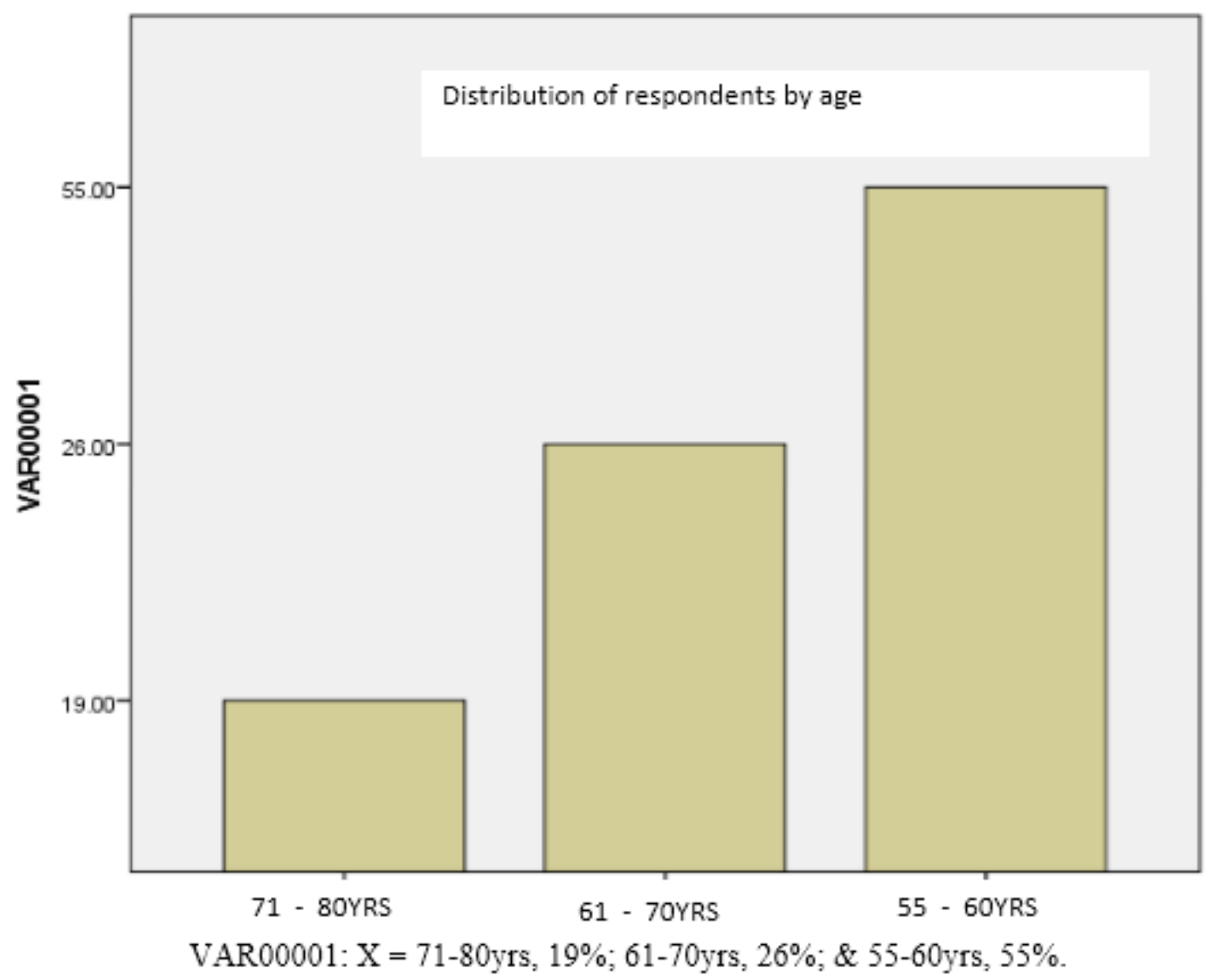

Figure 2. Distribution of Respondents by Age

Table 4. Description of Respondents by Religion

\begin{tabular}{llllll}
\hline S/No. & Religion & Male & Female & Total & $\%$ \\
\hline 1. & Christianity & 763 & 601 & 1364 & 42 \\
2. & Islam & 568 & 397 & 965 & 30 \\
3. & Traditional Religion & 483 & 404 & 887 & 28 \\
\hline & Total & $\mathbf{1 8 1 4}$ & $\mathbf{1 4 0 2}$ & $\mathbf{1 4 0 2}$ & $\mathbf{1 0 0}$ \\
\hline
\end{tabular}




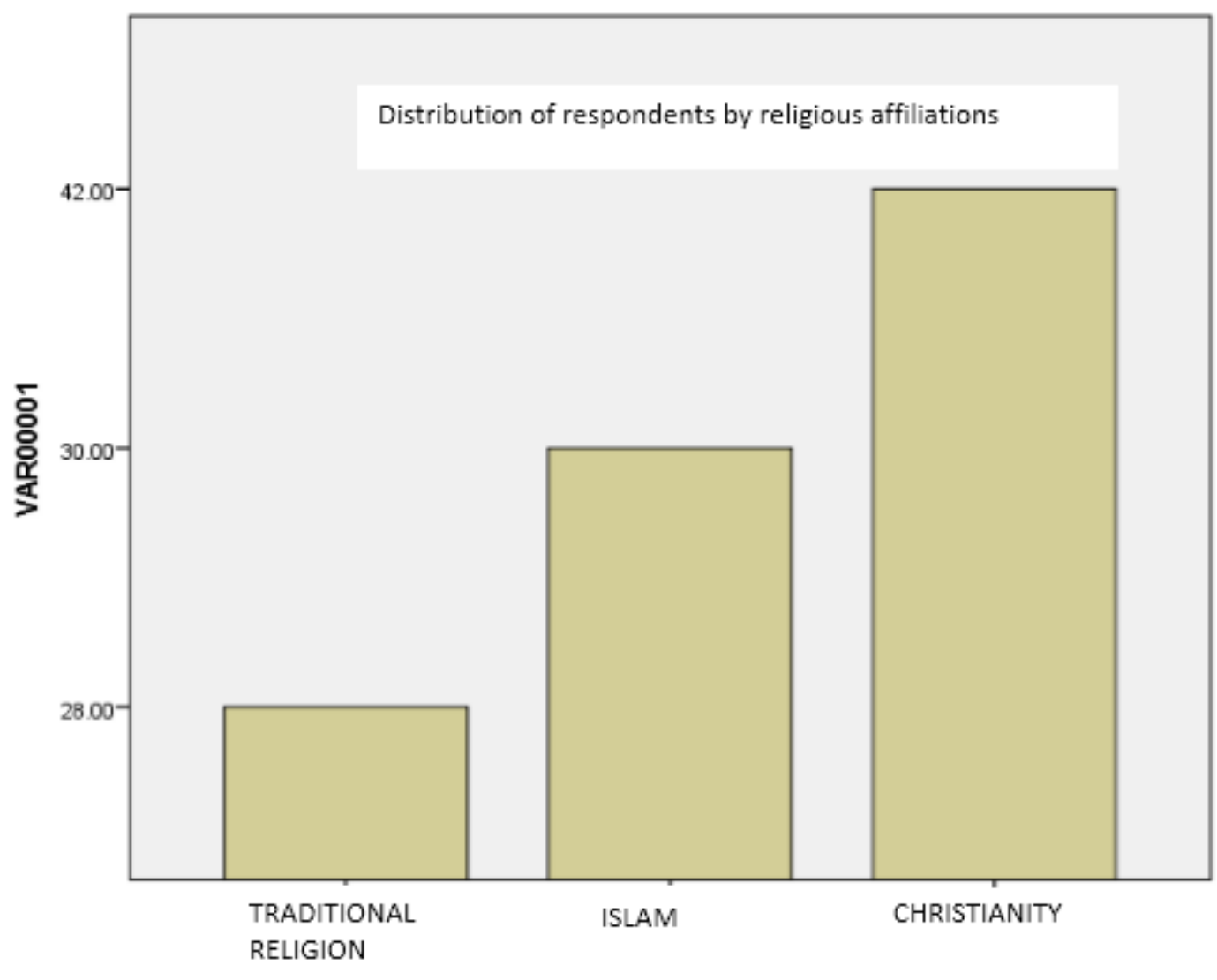

VAR00001: $\mathrm{X}=$ Traditional Religion, $28 \%$; Islam, 30\% \& Christianity, $42 \%$

Figure 3. Distribution of Respondents by Religious

\section{Data Analysis}

Table 5. Differences in Psychological Dimensions Across Nigerian Educational Policies

\begin{tabular}{|c|c|c|c|c|c|c|}
\hline $\begin{array}{l}\text { S/ } \\
\text { No }\end{array}$ & Items & $\begin{array}{l}\text { Colonial } \\
\text { educational } \\
\text { policy }\end{array}$ & $\begin{array}{l}\text { Pre-indepe| } \\
\text { dence educ: } \\
\text {-tion policy }\end{array}$ & $\begin{array}{l}\text { Post-indep } \\
\text { dence educ } \\
\text { tion policy }\end{array}$ & $\begin{array}{l}\text { New Nationa } \\
\text { Policy on } \\
\text { Education }\end{array}$ & Total \\
\hline 1. & $\begin{array}{l}\text { Purposefully addressing } \\
\text { learner's needs }\end{array}$ & 6555 & 9242 & 3517 & 3600 & 22914 \\
\hline 2. & $\begin{array}{l}\text { Taking care of individual } \\
\text { differences }\end{array}$ & 41021 & 7312 & 3400 & 3667 & 55400 \\
\hline 3. & Motivational tendencies. & 5402 & 18113 & 3700 & 4020 & 31235 \\
\hline 4. & $\begin{array}{l}\text { Attainment of self- } \\
\text { esteem. }\end{array}$ & 7345 & 8142 & 4321 & 5782 & 25590 \\
\hline 5. & $\begin{array}{l}\text { Provision of practical } \\
\text { vocational skills. }\end{array}$ & 6748 & 17936 & 4060 & 3372 & 32116 \\
\hline 6. & Attainment of life goals. & 5211 & 17885 & 4123 & 4571 & 31790 \\
\hline 7. & $\begin{array}{l}\text { Provides satisfaction of } \\
\text { stakeholders. }\end{array}$ & 3679 & 7342 & 4001 & 5877 & 20899 \\
\hline 8. & $\begin{array}{l}\text { Perceived as adequate by } \\
\text { employers. }\end{array}$ & 6213 & 16334 & 4206 & 3848 & 30601 \\
\hline 9. & Provision of self-respect & 4222 & 18768 & 5321 & 3933 & 32244 \\
\hline 10. & $\begin{array}{l}\text { Production of useful } \\
\text { practical skills. }\end{array}$ & 5442 & 7347 & 3678 & 5927 & 22394 \\
\hline 11. & $\begin{array}{l}\text { Production of } \\
\text { development skills. }\end{array}$ & 4882 & 8151 & 5747 & 4326 & 23106 \\
\hline
\end{tabular}




\begin{tabular}{|c|l|l|l|l|l|l|}
\hline 12. & $\begin{array}{l}\text { Provides potentials for } \\
\text { future usefulness. }\end{array}$ & 4341 & 7182 & 3819 & 3904 & 19246 \\
\hline 13. & $\begin{array}{l}\text { Aids personal } \\
\text { development of the } \\
\text { individual. }\end{array}$ & 5333 & 6400 & 3929 & 3712 & 19374 \\
\hline 14. & Teaching capacity. & 3892 & 7763 & 3866 & 4682 & 30203 \\
\hline 15. & Learner's satisfaction. & 6101 & 3412 & 3837 & 3504 & 16854 \\
\hline 16. & $\begin{array}{l}\text { Provides all-rounded } \\
\text { development. }\end{array}$ & 5881 & 5781 & 3688 & 3836 & 19186 \\
\hline 17. & $\begin{array}{l}\text { Conformity/compliance } \\
\text { potentials }\end{array}$ & 4324 & 18324 & 4898 & 3742 & 31289 \\
\hline 18. & $\begin{array}{l}\text { Potentials for the } \\
\text { development of high } \\
\text { standard social values. }\end{array}$ & 3691 & 8691 & 3601 & 3941 & 19924 \\
\hline 19. & $\begin{array}{l}\text { Provision of leadership } \\
\text { qualities }\end{array}$ & 4245 & 6334 & 3319 & 4022 & 27920 \\
\hline 20. & $\begin{array}{l}\text { Providing platform for } \\
\text { individual goal orientation } \\
\text { /achievement }\end{array}$ & 3426 & 15245 & 4933 & 3865 & 27469 \\
\hline & Total & 137954 & 215704 & 81964 & 84131 & 539754 \\
\hline & $\begin{array}{l}\text { Mean Points } \\
\text { Std Dev }\end{array}$ & $\begin{array}{l}42.90 \\
4.86\end{array}$ & $\begin{array}{l}67.07 \\
8.37\end{array}$ & $\begin{array}{l}25.49 \\
2.35\end{array}$ & $\begin{array}{l}26.16 \\
2.55\end{array}$ & $\begin{array}{l}41.96^{*} \\
4.87\end{array}$ \\
\hline
\end{tabular}

*Total mean score of all the Educational Policies in Nigeria.

\section{RESULTS AND DISCUSSION}

The study revealed that there has been changes in the availability of the psychological elements contained in the educational policies during the period under review The main thrust of the paper was to examine the depth of psychological contents and psychological relevance that were found in each of the Nigerian educational policies. It was discovered in the study that in educational policies where lower psychological background were recorded, the people expressed higher degree of dissatisfaction in the result of the policy and greater demand for reforms. This explains the relationship between psychological provisions (dimensions) and relevance of the education policy to the people's needs.

. In table 5, the study indicated that respondents rated the Pre-independence Education Policy as richer in psychological provisions (dimensions) than any other educational policy in the country. This is based on their assessment of what the educational policy offered to the people at that time based on the level of parental response and participation in the educational policy. Mean points were therefore as high as 73.29 $\mathrm{SD}=8.37$. This is followed by the Colonial Educational Policy with Mean=42.90, $\mathrm{SD}=4.86$, and then the New National Policy on Education with Mean=25.49, $\mathrm{SD}=2.35$, and lastly, The Post-independence Education Policy with mean points of $25.49, \mathrm{SD}=2.35$, respectively.

The Pre-independence Educational policy rated the highest in the psychological scale, depicting that it is psychologically higher in quality. Consequently, it was adjudged as having commanded higher parental response and participation as individual objectives were largely achieved (Osokoya, 2010). This is in line with the report of Wrings (2009), who highlighted that the Pre-independence Education Policy impacted greatly on the gains of the citizens across the whole nation.

Again, the Colonial Education Policy was rated higher in the scale and considered better than all the modern Educational Policies. It is therefore concluded that this also is comparatively higher in psychological elements (dimensions) than the Post-Independence 
and the New National Policy on Education. It was evident in the study that while the colonial Education Policy had mean points of 42.90; SD=4.86, the Post-Independence and New National Policy on Education had lower with Mean=26.16; SD=2.35 and Mean=25.49; $\mathrm{SD}=2.55$, respectively. Although, it was evident that the New National Policy on Education made provision for broader psychological processes, they were not clearly defined for direction and practical application.

Furthermore, the analysis generally revealed that the overall mean points of all the educational policies in the country summed up to as low as 41.96 as shown in the psychological scale. This is less than 50 points, thereby depicting the fact that psychological dimension is low in the educational policies over the years, and this calls for a serious attention. One notable factor is that the psychological elements enthrenched in most of the education policies were adequately expressed. On the other hand, the Pre-Independence Educational Policy which had above 50 points $(X=73.29)$ was also adjudged to have rendered better results in meeting the educational needs of the people. This to a great extent emphasizes the importance of the psychological dimension in educational policy formulation.

\section{CONCLUSION}

Educational policies are governmental policies of education aimed at meeting societal needs through utilization of the means of education. In Nigeria from the period of colonial rule till date there have been several education policies. Educational policies under study were four; colonial education policy of 1877 , pre-independence education policy of 1952, Postindependence education policy of 1967 and the new national policy on education of 1969.

The colonial educational policy examined the period when schools were established and control by the missionaries to the period schools were taken over by the colonial government. The colonial education policy which is basically aimed at literacy was well designed to meet the aspiration of the society but little focus on individual aspiration and perception of the people the policy is meant to serve. In the Pre-Independence Education Policy the study examined the period of indigenous eminent Nigerians took over in the management of the nation's educational system and reforms made in respect of the demands of the Nigerian society. In the study, the Post Independence Educational policy of 1967 highlighted all the policies and reforms made after harmonizing all the educational policies of the regions/states to the point where Nigerian National Policy on Education was promulgated and subsequent changes were made. Both the pre-independence and the post-independence policies moved away from basic literacy to science and technology. Yet, major part of these educational policies lack the psychological dimensions and relevance to the people. Then the new national policy on education which took off in Nigeria in 1983 was a more comprehensive policy yet the psychological question has not been clearly identified.

It was generally observed that none of these policies had a high level of psychological relevance hence the fallen standard of education and the difficulty with which they were implemented to achieve set objectives. It could be said that none of the policies could claim seventy percent achievement level. This is due to the neglect of the psychological dimension of policy development and implementation. It was therefore that:

i. The psychological dimension in the educational policy should be enriched.

ii. During needs assessment, the psychological implication of needs and their satisfaction should be carefully identified and handled.

iii. There should be effective mechanism to tackle extraneous factors that are arising from policy implementation. 


\section{REFERENCES}

Adenuga, A. A. (2018). Religious value for nation building. Retrieved on June, 13, 2019 from www.bet.antistle.230146317/religious-values-for-nation-building-html.

Adler, M. J. (1982). The Paidee Proposal: An-educational manifesto. New York-Macmillia.

Amba, T. S. (2012). History of Education in Nigeria. Enugu: Leeward.

Baumgardener, J. (2019). First thing. Retrieved on Oct. 3, 2019 from www. https//firstthings.org./3-things-each-person-in-yourfamily-needs-to-know.

Benwari, N. (2014). Curriculum implementation in Nigeria. In A. A. Adeyinka, E.E. Osuji, T. T. Asuka, A.O. Orubu \& A.A. Agih (Eds) Integrated foundations of Education, 1, 91.

deMarrais, K.B. \& LeCompte, M.D. (1995). The way schools work: A Sociological analysis of education. Longman New York.

Emeh, L. (2007). Curriculum development and implementation. Calabar: Eti-Nwa.

Fafunwa, A.B. (2004). History of Education in Nigeria. Ibadan NPC Educational Publishers.

Ferari, M. (2018). Societal values and schooling. New York: Macmillan.

Kan A. (2017). School, curriculum and the society. Retrieved on September 20, 2019 from https//www.femiamao.com.>value.html pelt

Hultsjo, S., Bertero C \& Hielin, K. (2007). Perceptions of Psychologic care among foreignand Swedish-born people with psychotic disorders. Journal of Nursing, 60 (3) 279-288.

Lein-Batman, B. (2018). Role of teachers in curriculum implementation. Benin: Oloigbere publishers

Maslow, A. H. (1943). A theory of human motivation. Psychological Review, 50(4) 370- 369

Maslow, A. H. (1954). Motivation and personality. New York: Harper and Row.

National Population Commission (2006). 2006 Nigeria Population Census. https//www.prb.org/objectionsovernigeriancensus/458345. Html.

Okechukwu, A. (2007). Education and politics in Nigeria. Lagos: Adebayo.

Rundell, M. (2007). Macmillan English Dictionary for advanced learners. London: Macmillan.

Sharma, A. (2019). Seven essential functions of a school as an agency of education. www.preservearticles.com/education/7-essential-functions-of-a-school. as-an-agencyof-education/2615 litml.

Tyack, D. B. (1988). Ways of Seeing: An essay on the history of compulsory schooling. In R.M. Jaeger (Ed), Complementary methods for research in education. Washington, D.C. American Educational Research Association.

Weber (2010), Nursing care of families with parents who are lesbian, geny, bisexual or transgender. Journal of child and adolescent psychoactive Nursing, 23 (1) 11-16.

Wrings, S. S. (2009). History of Nigerian Education. Owerri: Totan.

Whitson, C. (2017). The Nigerian Educational system: past, presence, future. Lagos: Thomas Nelson. 